\title{
Affective Polarization and the Populist Radical Right: Creating the Hating?
}

\author{
Eelco Harteveld ${ }^{1}$, Philipp Mendoza ${ }^{2}$ and Matthijs Rooduijn ${ }^{1 \star(D)}$ \\ ${ }^{1}$ Department of Political Science, University of Amsterdam, Amsterdam, Netherlands and \\ ${ }^{2}$ Amsterdam School of Communication Research, University of Amsterdam, Amsterdam, Netherlands \\ ${ }^{*}$ Corresponding author. Email: m.rooduijn@uva.nl
}

(Received 15 September 2020; revised 7 June 2021; accepted 14 June 2021;

first published online 7 October 2021)

\begin{abstract}
Do populist radical right (PRR) parties fuel affective polarization? If so, how and under which circumstances? Based on a comparative cross-country analysis covering 103 elections in 28 European countries and an examination of longitudinal data from the Netherlands, we show that PRR parties occupy a particular position in the affective political landscape because they both radiate and receive high levels of dislike. In other words, supporters of PRR parties are uniquely (and homogeneously) negative about (supporters of) mainstream parties and vice versa. Our analyses suggest that these high levels of antipathy are most likely due to the combination of these parties' nativism and populism - two different forms of ingroup-outgroup thinking. Our findings also suggest that greater electoral success by PRR parties reduces dislike towards them, while government participation appears threatening to all voters except coalition partners.
\end{abstract}

Keywords: populism; radical right; affective polarization; public opinion

Affective polarization is impacting democracies across the globe. In their seminal study of the USA, Shanto Iyengar et al. (2012) documented the widening fault line between supporters of the Democrats and Republicans, characterized by mutual distrust, an unwillingness to interact or engage, outright discrimination and even support for political violence (see also Finkel et al. 2020; Hetherington and Rudolph 2015; Kalmoe and Mason 2018; Martherus et al. 2021; Strickler 2018; Tappin and McKay 2019). Americans perceive the two camps along the lines of an 'ingroup' and 'outgroup'. Recent studies have shown that affective polarization is also prevalent in other countries, and to sometimes even stronger degrees than in the US (Reiljan 2020; Wagner 2021; Westwood et al. 2018). At the same time, its severity varies substantially between countries, and it has waxed in some countries and waned in others (Boxell et al. 2020). While our understanding of the mechanisms underpinning affective polarization is growing, we lack a

(c) The Author(s), 2021. Published by Cambridge University Press on behalf of Government and Opposition Limited. This is an Open Access article, distributed under the terms of the Creative Commons Attribution licence (http://creativecommons.org/licenses/by/4.0/), which permits unrestricted re-use, distribution, and reproduction in any medium, provided the original work is properly cited. 
comprehensive comparative agenda (Gidron et al. 2019a) to explain this variation between countries and over time. Within this emerging comparative perspective, an underexplored area is the role of the political supply side. How does affective polarization in a given society depend on developments on this supply side?

In this study we explore the role played by populist radical right (PRR) parties in fuelling a polity's affective polarization. PRR parties form the most successful, but also the most controversial, new party family to have emerged in previous decades. Their emergence and establishment likely shakes up citizens' views of their political opponents - either as a supporter or a strong detractor of the PRR. Indeed, previous studies have suggested that PRR parties are associated with an unusual degree of affective polarization, a phenomenon called PRR 'exceptionalism' (Gidron et al. 2019b; also see Helbling and Jungkunz 2020). Yet the mechanisms creating this exceptionalism are not yet well understood. Neither is it clear which factors exacerbate or dampen this heightened hostility. Our study aims to fill this gap in three main ways: (1) by more extensively theorizing the mechanisms creating this phenomenon; (2) by disentangling, theoretically and empirically, the role played by populism and the host ideology; and (3) by exploring how this phenomenon is moderated by context.

Our central hypothesis is simple: we expect PRR supporters and supporters of mainstream parties to dislike each other to an unusually strong and homogeneous degree. PRR parties combine populism with nativism, and both of these sets of ideas place antagonistic divisions - 'the people' versus 'the elite' as well as natives versus non-natives - at the centre of their politics. In PRR parties' narrative 'the people' and 'the elite' are locked in a Manichean struggle, and the elite conspires with non-native elements such as immigrants, business elites or international organizations. This approach to politics as a moral struggle between a clear-cut 'ingroup' and 'outgroup', expressed in antagonistic party messages, can be expected to amplify negativity towards political outgroups among PRR supporters. In turn, opponents of PRR parties can be expected to react strongly to the attacks implied in these messages and, realigned into an 'anti-populist' camp (Moffitt 2018), to be disapproving of PPR parties and their supporters in response (Mendélez and Kaltwasser 2021). This dislike of the PRR might well be amplified by the strong stigma attached to these parties' nativist agenda (Blinder et al. 2013; Harteveld et al. 2019). If we want to understand the antipathy characterizing contemporary politics, it is crucial to know how PRR parties and partisans contribute to this development as either senders or recipients of such dislike.

Importantly, we expect developments on the supply side - specifically, PRR parties' electoral success and their government participation - to matter for this relationship. Here, we formulate competing expectations. It is theoretically plausible to expect such success or inclusion to exacerbate antipathy towards PRR supporters, but it might equally plausibly reduce it. On the one hand, supporters of mainstream parties are likely to perceive electoral successes of PRR parties, and their representation in government in particular, as a political threat. Adding threat to intergroup competition heightens outgroup bias (Brewer 1999), thus likely boosting negative affect towards the PRR. On the other hand, growing support for a PRR party and inclusion in office can signal political acceptability of the PRR, so it is also plausible that increasing support and inclusion make mainstream parties less negatively disposed towards PRR supporters. 
In short, we aim to answer four questions. First, is there an 'affective gap' between the PRR and its opponents, and how does it compare to dislike between supporters of mainstream parties? Second, is this dislike applied more homogeneously than dislike towards other parties? Third, is it PRR parties' nativism or populism that triggers the dislike? Fourth, can the PRR's ongoing electoral success and even government participation be expected to reduce or further inflame affective polarization?

We study these questions using two complementary data sources. First, we study the hypotheses using Comparative Study of Electoral Systems (CSES) data that cover 696 parties from 28 European countries over 20 years. This provides a test of the relation between PRR supporters and their opponents in a variety of settings. It also provides ample variation in PRR success and government inclusion. After establishing the patterns across Europe, we use individual-level panel data for a more stringent test of the mechanisms in the case of the Netherlands. We use the Longitudinal Internet Studies for the Social Sciences (LISS) panel, which covers ten yearly waves - including an episode of government inclusion of the PRR party Partij voor de Vrijheid (PVV, Party for Freedom) as a prominent support party. In addition, the latest wave of the LISS panel allows us to use a more direct operationalization of affective polarization. This measure does not examine citizens' evaluations of other parties, but their assessments of those who vote for these parties, which is at the heart of the concept (Iyengar et al. 2012). Combining these two data sets allows us to strengthen both the external and internal validity of our study.

Our analyses indicate that, as expected, PRR supporters occupy a unique position in the affective political landscape. They are uniquely negative about mainstream parties and their supporters. At the same time, supporters of mainstream parties are uniquely negative about (supporters of) PRR parties. Interestingly, our findings suggest that it is both PRR parties' nativism and their populism that lead to such high levels of radiated and received dislike: parties of the populist radical left (i.e. parties that do employ populism but eschew nativism) are also relatively disliked and disliking, but to a less extreme extent. We also find that developments on the supply side matter, but not straightforwardly. As PRR parties gain electoral success, they generally receive more sympathy from mainstream voters, while government participation is associated with less sympathy, except from coalition partners.

Our findings have important academic and societal implications. Dislike between the PRR and the mainstream is a two-way street, rooted in the double ingroup-outgroup logic - of populism and of nativism - these parties introduce, as well as the disapproval they receive in return. The establishment of PRR parties to a political system thus provides a double boost of antipathy to the system. As these parties continue to grow, such antipathy might be reduced, but as PRR parties increasingly gain government access, a backlash might occur. Once the ideological differences between mainstream and PRR parties get supplemented with ingroupoutgroup thinking and feelings of enmity, or even hatred, along party lines, it becomes increasingly hard to make political compromises. This could have severe consequences for the functioning of liberal democracies. 


\section{PRR parties, affective polarization and political context}

Below, we discuss how the combination of populism and nativism inherent to the PRR ideology is likely to increase affective polarization. We then continue to discuss how this effect might be moderated by electoral success and government inclusion.

\section{The populist radical right}

PRR parties have become increasingly successful in Europe. Two decades ago, about $5 \%$ of the electorate supported such parties. Today, almost $15 \%$ cast a ballot for a PRR party (popu-list.org; see also Lewis et al. 2018). One of the reasons for this party family's electoral performance is the successful combination of two ideological features: nativism and populism (see Rydgren 2007). Nativism is 'an ideology, which holds that states should be inhabited exclusively by members of the native group ("the nation") and that nonnative elements (persons and ideas) are fundamentally threatening to the homogenous nation-state' (Mudde 2007: 19). Nativism is, in other words, a highly exclusionist form of nationalism; it not only emphasizes the positive characteristics of one's own nation, it also underlines the negative features of 'dangerous others' - people of another race, religion or ethnic background (Carter 2018; Rydgren 2007). Populism can be defined as a set of ideas 'that understands politics as a Manichean struggle between a reified will of the people and a conspiring elite' (Hawkins and Kaltwasser 2019: 3). As such, it emphasizes the antagonistic relationship between the good, virtuous people and the evil, corrupt elite (Hawkins 2010; Panizza 2005).

Many scholars have emphasized that it is important to analytically distinguish between nativism and populism. Whereas nativism concerns a 'horizontal' relationship between the nation and non-natives, populism stresses the 'vertical' relationship between the people and the elite (Ionescu and Gellner 1969; Mény and Surel 2002). These two phenomena need not always occur together: there are, for instance, many populist parties that are not nativist - only think of left-wing populists like Podemos in Spain or Syriza in Greece, or parties that have no clear left-wing or right-wing outlook like the Movimento Cinque Stelle (M5S, Five Star Movement) in Italy. Conflating the two concepts can lead to highly flawed conclusions about the causes and consequences of nativism and populism (Bonikowski 2017; De Cleen et al. 2018; Rooduijn 2019).

At the same time, it is important to emphasize that nativism and populism do have an important common denominator: they share the tendency to strongly favour an 'ingroup' (the nation or the people) and to be hostile towards an 'outgroup' (non-natives or the elite). Nativism and populism are, in other words, concrete manifestations of ingroup-outgroup thinking (Adorno et al. 1950; Tajfel and Turner 1979). Hence, both nativism and populism are Manichean or antagonistic worldviews according to which the world is divided into good and evil, into us and them, into friend and foe (Hawkins 2010; Panizza 2005). Consequently, both messages involve a strong tendency to moralize politics (see Mudde 2004).

Because nativism and populism share this Manichean outlook, they can convincingly be combined. According to the 'master frame' of the PRR, the 'real' Britons, the 'real' Dutch and the 'real' Austrians are betrayed by a cosmopolitan elite that 
promotes internationalism, cosmopolitism and multiculturalism, and thereby undermines the national identity and the interests of the 'own', native people (Rydgren 2007). Hence, the nation is being threatened by a conspiracy of elites and non-natives (immigrants, Muslims or ethnic minorities) who neglect what ordinary people find important. As a result, the country is in a severe crisis which can only be solved by dismantling the establishment and by making immigration- and integration-related policies much more restrictive. ${ }^{1}$

\section{PRR parties and affective polarization}

We expect that the PRR's antagonistic and polarizing messages will fuel ingroupoutgroup thinking among citizens. More specifically, like Noam Gidron et al. (2019b), we expect them to fuel affective polarization between, on the one hand, supporters of PRR parties and, on the other, supporters of mainstream parties. Affective polarization generally refers to a situation of antipathy between citizens based on their respective political identities. As such, affective polarization is related to, but distinct from, ideological polarization, which is the extent to which citizens disagree on actual issues or issue dimensions. Rather than (merely) being rooted in disagreement (Iyengar et al. 2019; Lelkes 2018; Reiljan 2020), affective polarization reflects intergroup dynamics and can thus be expected to be fuelled by nativist and/or populist ingroup-outgroup ideas. Like any other social identity (Tajfel and Turner 1979), an identification with a political camp has affective and behavioural implications, among them a disposition to like and favour the ingroup ('us') and - under certain conditions - derogation of the outgroup ('them'). Affective polarization captures this 'affect gap' towards the political outgroup. ${ }^{2}$

We expect the Manichean streak of both populism and nativism to influence the way political outgroups are perceived, and hence to matter for affective polarization. As we have seen, rather than merely being ideological opposites, populists accuse their competitors of being part of (or aligning with) morally compromised elites and selling out 'the people'. Gidron et al. (2019b) argue this might foster a particular dislike by PRR supporters towards the mainstream. On top of their populist claim, radical right-wing populists add the assertion that non-natives are threatening the nation state. As noted, it is often argued that the elite and 'dangerous' others are in cahoots with one another. This accusatory stance likely affects the views of their supporters and opponents too. Like all voters, PRR supporters take cues from their party (Harteveld et al. 2017; Rooduijn et al. 2016). This - combined with the strongly antagonistic and thereby polarizing nature of PRR messages suggests that, among PRR supporters, the PRR's accusation of moral corruption of the mainstream party elites and of conspiring with (dangerous) minority groups can easily spill over into a condemnation of their supporters. It is therefore plausible that PRR voters judge their fellow citizens harshly for supporting a mainstream party:

Hypothesis 1a: Supporters of PRR parties will dislike (supporters of) mainstream parties more than mainstream party supporters dislike (supporters of) other mainstream parties. 
Conversely, the presence of PRR parties is also likely to fuel antagonistic ingroupoutgroup thinking among mainstream party supporters. This is because mainstream supporters will feel directly attacked and because many have a deeply rooted disapproval of the populist and nativist claims. Carlos Meléndez and Cristóbal Kaltwasser (2021) report that over half of all Europeans indicate they would never vote for the populist radical right, which is a higher level of negative partisanship than reported regarding any other party family. By shifting the playing field to the question of how politics is done, sustained PRR presence realigns and crystallizes the mainstream into an anti-populist camp (Moffitt 2018). Such mainstream party affiliates see themselves or their ideas at the receiving end of hostile messages, and as a result likely respond with a stronger affective distance towards PRR parties than towards their other political competitors.

Moreover, in their nativist policy positions and discourse, PRR parties are seen by many to approach, and sometimes cross, the boundaries of social and legal norms regarding prejudice (Blinder et al. 2013). As a result, these parties tend to be 'stigmatized' by large swathes of the population (Harteveld et al. 2019). While this stigma is rooted in distance on the cultural dimension, it goes beyond it. From the point of view of many mainstream citizens, PRR supporters are not merely taking a distant ideological position but one that is categorically unacceptable. In other words, we expect that being at the receiving end of PRR criticism as well as deep-rooted disapproval of PRR's populist and nativists positions, further delegitimized by the presence of a stigma, will lead to increased levels of dislike among supporters of mainstream parties. ${ }^{3}$ Indeed, Marc Helbling and Sebastian Jungkunz (2020) report exactly such dislike towards PRR supporters. ${ }^{4}$ Hence, we expect:

Hypothesis 1b: Supporters of mainstream parties will dislike (supporters of) PRR parties more than (supporters of) other mainstream parties.

In other words, among PRR supporters the enduring exposure to nativist and populist messages can be expected to lead to attitudes of disfavour towards the outgroup specified in the antagonistic message, whereas mainstream party supporters' dislike is likely to develop towards the party or parties that express such antagonistic messages to the point of breaching social norms against prejudice. As a result, both groups can be expected to look upon each other disfavourably. The result is a mutually hostile 'populism-anti-populism divide' that should be studied in its entirety that is, both the populist and anti-populist sides of the divide need to be examined (Stavrakakis 2014; Stavrakakis and Katsambekis 2019).

\section{Homogeneity of dislike}

We expect dislike across the PRR-non-PRR divide not only to be uniquely strong, but also to be applied homogeneously. The populist critique of mainstream parties goes beyond the programmatic and stresses the interchangeability of mainstream parties, regardless of whether they are left or right. In other words, PRR supporters can be expected to dislike all other partisan groups to a relatively homogeneous extent. Similarly, the dislike towards PRR supporters, being partly rooted in these parties' general stigma, can also be expected to be perceived relatively homogeneously by the supporters of all mainstream parties. Indeed, there is evidence 
that voters of the mainstream right are often strongly disapproving of the populist radical right too (Harteveld 2021). If so, ideological distance - the extent of actual substantive disagreement - should be a weaker predictor of dislike by and towards the PRR:

Hypothesis 2a: PRR supporters' dislike towards (supporters of) mainstream parties depends less on ideological distance than dislike among mainstream supporters.

Hypothesis 2b: Mainstream supporters' dislike towards (supporters of) PRR parties depends less on ideological distance than dislike among mainstream supporters.

\section{Nativism or populism?}

As argued, PRR parties are both nativist and populist, and it is likely that these two messages reinforce each other when it comes to ingroup-outgroup thinking among citizens. Although it is beyond the scope of this (observational) study to isolate the origins of this dislike with inferential certainty, we explore whether it is their nativism or their populism that triggers the dislike by examining supporters of populist radical left parties too. ${ }^{5}$ We expect the same mechanisms to apply, yet to a lesser extent. After all, such parties express only one of the two antagonisms: the people versus the elite. Moreover, populist radical left parties do not share the stigma associated with strong nativism, which we expected to be an important factor shaping the views towards PRR supporters. As a result, while populist radical left supporters are likely to be relatively disliking towards, and disliked by, mainstream voters, we expect this to be much less pronounced than the antipathy around PRR supporters, and explore this throughout the analysis section.

\section{The moderating role of electoral success and government participation}

In short, PRR parties are likely to increase the overall levels of affective polarization by being the sender and/or recipient of unique and homogeneous dislike. Yet we expect that the extent to which dislike is being sent or received also depends on the political context. More specifically, we surmise that the electoral success and government participation by PRR parties will play a particularly important role. Below we formulate two competing hypotheses about this possible moderation effect and label these the power threat and the legitimation hypotheses.

Social Identity Theory teaches that ingroup favouritism - that is, liking your own party and its supporters - does not automatically lead to outgroup bias (i.e. dislike of your political opponents) (Brewer 1999). However, under some conditions it does. One of these is a context of threat (see Feldman and Stenner 1997). Arguably, if PRR parties grow in electoral support or gain access to the halls of power, they will be perceived as a greater threat to those vehemently opposed to them. As a result, electoral success and government inclusion should increase antipathy towards PRR parties. ${ }^{6}$

Hypothesis 3: Mainstream party supporters' dislike of PRR supporters increases when PRR parties (a) grow in electoral support or (b) enter government (power threat hypothesis). 
On the other hand, growing support among the population at large and inclusion in government can also signal acceptability and even legitimacy. Electoral success shows that a substantial share of one's fellow citizens approve of this party in large numbers; inclusion in government shows that some political parties apparently approve enough of this party to cooperate with it. Such signals from parties matter because citizens are susceptible to elite cues (Cohen 2003; Zaller 1992) and coalition participation has a powerful cueing effect (Anderson and Tverdova 2001; Blais and Gélineau 2007). That would lead us to formulate a reversed expectation that, in the case of both growing electoral support and government participation, supporters of mainstream parties might actually dislike PRR supporters less. ${ }^{7}$

Hypothesis 4: Mainstream party supporters' dislike of PRR supporters decreases when PRR parties (a) grow in electoral support or (b) enter government (legitimation hypothesis).

It is possible that any increase in sympathy is restricted to the actual coalition partners (which are often parties of the mainstream right). After all, sharing a coalition functions as a heuristic: it makes coalition partners appear as more ideologically similar and therefore likeable (Fortunato and Stevenson 2013). To distinguish a legitimation effect from a coalition heuristic effect, the increase in sympathy should be visible among those outside the coalition too.

We test all our hypotheses with two studies. In the first study we investigate our hypotheses comparatively with cross-sectional data of electoral surveys. In the second study we test the same expectations more in depth based on a Dutch panel survey. These two studies complement each other in their strengths. The cross-sectional data allow us to assess to what degree our findings hold across contexts. The panel data set allows us to control for potentially confounding variation between individuals, and, moreover, includes a more direct operationalization affective polarization.

\section{Study 1: Comparative data (CSES) \\ Data}

For our first study we rely on data of the Comparative Study of Electoral Systems project (CSES 2019), a data set of compiled electoral surveys covering elections in 55 countries between 1996 and 2019. ${ }^{8}$ The CSES includes measures of respondents' sympathy towards parties just before or after elections, at a time when they are primed with partisan identities, and thus to think of themselves in association with or distance from certain parties. To classify populist parties (of the radical left and right subtype), we connect these data to the second version of the PopuList (Rooduijn et al. 2019), which offers classifications of European parties since 1989, and the Parliaments and Governments Database (ParlGov; Döring and Regel 2019). We link these two data sets via the PartyFacts platform, which offers harmonized party identifiers that allow us to link data sets. Given the European focus of the PopuList, the data set is here reduced to 103 elections across 28 European countries. This provides reasonable variation in government participation by PRR parties (11 times). ${ }^{9}$ 


\section{Operationalizations}

Our main dependent variable is respondents' sympathy towards each competing party on a scale from 0 ('strongly dislike') to 10 ('strongly like'). We arrive at respondents' partisan 'ingroup' by relying on their party identification ('Do you feel closer to any particular party ...?'), or if this is missing by their highest proclaimed party sympathy or their vote choice. We distinguish supporters of PRR parties from four other party families: mainstream left parties (social democratic parties), mainstream right parties (liberal, conservative and Christian democratic parties), green parties and populist radical left parties. Green parties clearly position themselves on the anti-populist side of the populism-anti-populism divide. However, because not all scholars agree on classifying green parties as mainstream parties (see Meguid 2005), we have included them separately from the social democrats. As noted in the theory section, populist radical left parties are included to explore the relative role of populism and nativism: these parties share the ideological feature of populism with the PRR, but not the feature of nativism.

Ideological distance (for $\mathrm{H} 2 \mathrm{a}$ and $\mathrm{H} 2 \mathrm{~b}$ ) is operationalized by calculating the absolute distance between a respondent's ideological left-right self-placement on an 11 -point scale $(0=$ left, $10=$ right $)$ and the ideological position of the outparty on the same scale (as reported by the expert judgements provided by CSES), resulting in a dyadic ideological distance variable that ranges from 0 to 10 . As a robustness check (presented in Online Appendix D), we replicated the model using distance on the topics of multiculturalism and national way of life, as reported in the inparty's and outparty's manifestos (Volkens et al. 2019). ${ }^{10}$ This theme - and the broader dimension of cosmopolitanism versus nationalism for which it stands - is at the core of the nativist platform of PRR parties.

We measure electoral support by parties' vote share. As the CSES surveys were collected just before or after elections, we measure government participation in terms of a party competing in an election as an incumbent government party. This means we gauge the effect of government participation at a moment when this participation is (usually) drawing to an end. Any legitimation effect should arguably outlast the length of the government inclusion episode, but it is conceivable that any threat effect has somewhat waned when the end of the period is in sight. (Study 2 will allow us to gauge the impact of participation during the coalition episode.)

\section{Model}

We have transformed the original CSES data into a 'stacked' (or 'long') data set with directed voter-party dyads as the new units of analysis. This means that for each respondent there are multiple observations - one for each party they evaluated. As a result, depending on the item response missingness, in each country there are as many voter-party dyads as there are respondents multiplied by the number of parties (see Dahlberg 2013). In our main models we predict sympathy, in this dyadic data, by the respondent's inparty party family, the family of the party that is being evaluated ('outparty') and the interaction between the two. ${ }^{11}$ This 'base' model captures the sympathy expressed between each combination of party families. We then include additional interactions: once with ideological distance 
(for $\mathrm{H} 2 \mathrm{a}$ and $\mathrm{H} 2 \mathrm{~b}$ ) and once with the size of the electorate and a dummy for government participation ( $\mathrm{H} 3$ and $\mathrm{H} 4$ ). (The latter we additionally interact with government participation by the inparty, to distinguish coalition heuristics.) All models contain country-fixed effects as well as random intercepts on the country-election level and robust standard errors. Because three-way and four-way interactions are difficult to interpret, we visualize the predicted probabilities and marginal effects pertaining to the respective hypotheses in the main text and report the regression tables in Online Appendix A.

\section{Findings}

Dislike between PRR supporters and others

We start by exploring the sympathy towards various parties at the individual level. Figure 1 presents the predicted average sympathy scores towards the respective outparty families by the party family affiliation of the respondent. It shows that sympathy towards PRR parties is especially low among green supporters (with an average below 2.0 out of 10), but that such dislike is rather universal. Even among the ideologically closer supporters of the mainstream right, PRR parties receive a sympathy score of below 3.0, which is lower than the scores handed out to the mainstream left or the greens. In return, the scores handed out by PRR supporters are low too: around 2.9 towards the left and 3.8 towards the right. Yet these are still higher than the scores handed out towards them by the left. All in all, these figures are in line with both H1a and H1b: levels of sympathy by PRR supporters towards the mainstream are consistently low, as is dislike by mainstream supporters towards the PRR.

In the case of populist radical left parties, the pattern is similar but weaker. They too are relatively disliked, especially by the mainstream right, but less consistently so by all party families. Similarly, they too are relatively negative towards all party families, but again to a lesser extent and less homogeneously so than the PRR. This tentatively suggests an 'additive' explanation in which populism plus the host ideology of nativism together shape reactions by and towards the PRR. We will return to this notion later.

The fact that PRR parties both attract and radiate so much dislike suggests that on the aggregate level affective polarization will be higher if PRR parties are larger. When aggregated to the country-wave level, the correlation between PRR support and average sympathy towards outgroups is $r=-0.28$, making countries with stronger PRR support significantly more affectively polarized. This correlation, while negative as expected, appears partly driven by the case of Hungary in 2018, which features both the strongest support for a PRR party in our data and a very large dislike towards outgroups. Without this case, the correlation is $r=-0.17$. In short, the differences in affective polarization between countries is predicted by the size of the PRR party, but only moderately so. This shows that many other factors influence affective polarization (see Gidron et al. 2019b; Reiljan 2020), in addition to reflecting noise in the measurement of affective polarization through average party sympathy measures. Still, the analysis in Figure 1 shows that antipathy between PRR parties and their opponents is indeed exceptional in its degree. 


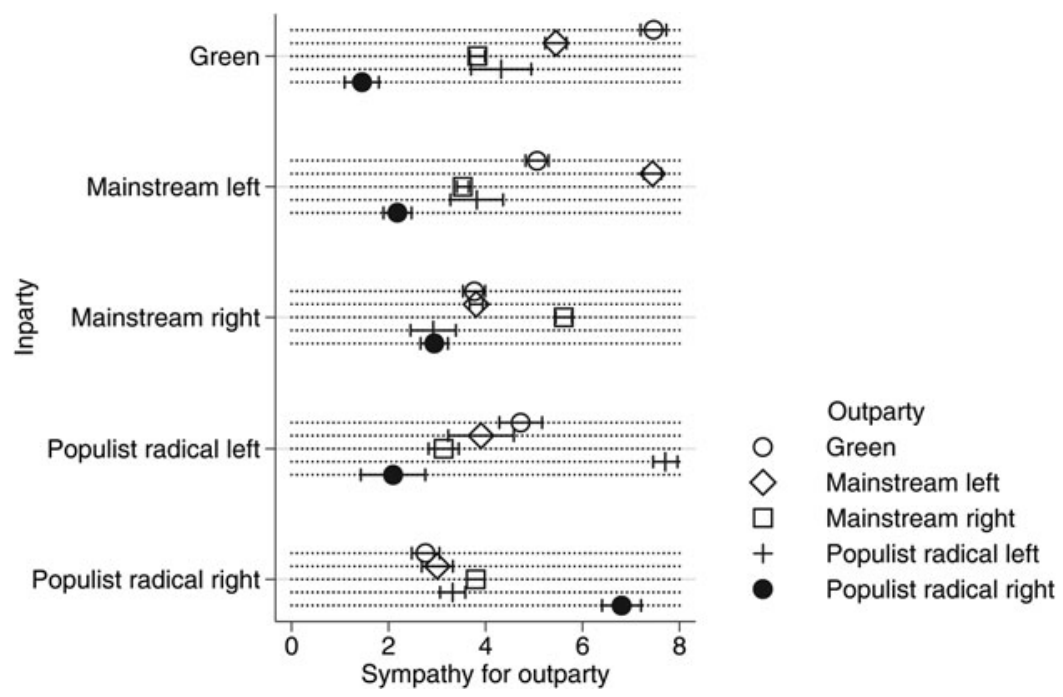

Figure 1. Predicted Sympathy towards Parties, by party family Note: Based on Online Appendix A, Table 1.

\section{A homogeneous dislike?}

Another pattern that emerges in Figure 1 is that PRR supporters provide relatively low scores to all outparties, regardless of party family, whereas mainstream party supporters differentiate more in their views of parties. This suggests, as predicted by $\mathrm{H} 2$, that ideological distance matters relatively little in shaping dislike by and towards the PRR.

For a more formal test, Figure 2 shows the results of a regression in which sympathy towards the outparty, in the dyadic model, is explained by inparty and outparty party family dummies, ideological distance and the interaction between all of these. Because our hypotheses refer to the two camps of the PRR and the rest, the inparty and outparty classification have been reduced to 'Populist radical right' versus 'Other'. Because the coefficients of these higher-order interactions, presented in Online Appendix A, are again difficult to interpret, we inspect the marginal effects visually. Figure 2 presents the marginal effects of ideological distance on the sympathy score towards both PRR parties (diamond) and other parties (circle). It does so for supporters of PRR parties (lower section) and other parties (upper section).

All effects are negative, as is to be expected: the larger the distance between a respondent's ideological self-placement and the outparty's ideology, the lower the sympathy is. However, this correlation is not equally strong in all cases. Sympathy by mainstream voters towards other mainstream parties is governed more strongly by ideological distance than their sympathy towards PRR parties. Conversely, sympathy by PRR voters towards the mainstream also depends less on ideological distance than sympathy within the mainstream. This confirms that dislike towards and by the PRR is applied relatively homogeneously.

A replication using distance on the issues of multiculturalism and national way of life (based on MARPOR; see Online Appendix D) as a proxy for nativism yields 


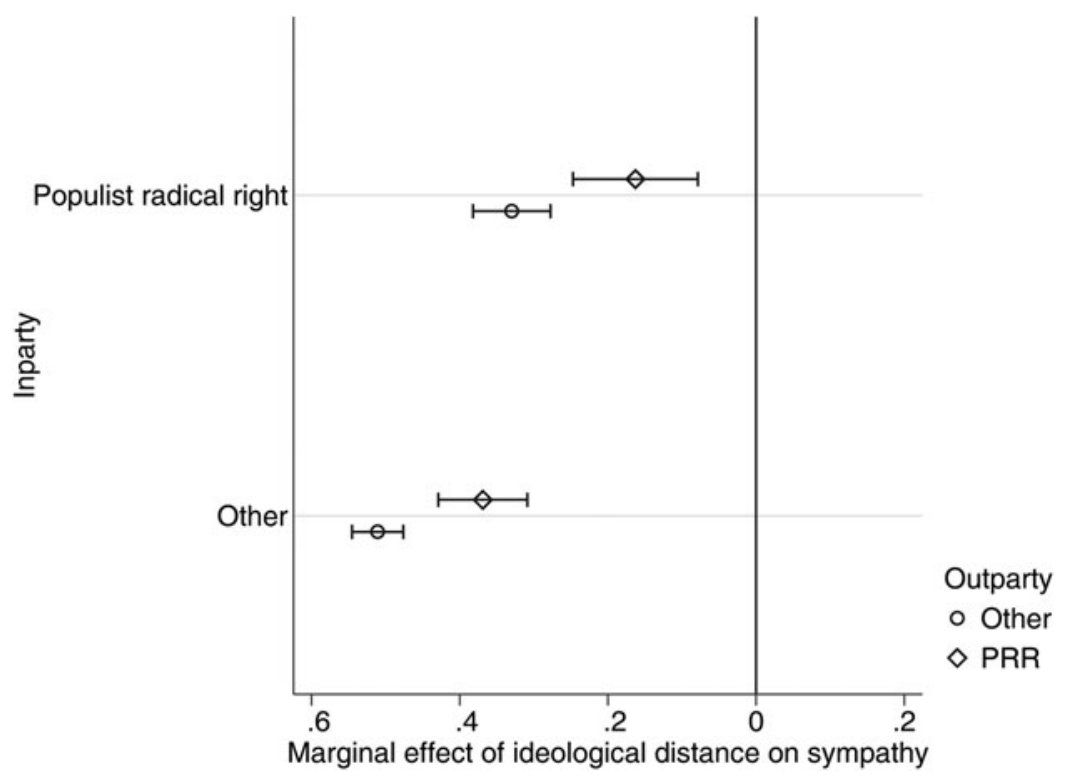

Figure 2. Marginal Effect of Ideological Distance on Sympathy towards Outparties, by PRR v. Other Note: Based on Online Appendix A, Table 2.

even stronger support for this conclusion. Dislike between mainstream parties is shaped four times as strongly by ideological distance on the nativism proxy than sympathy by and towards the PRR. We conclude that, as expected, affective distance between the PRR and the rest goes beyond the ideological distance between them.

The role of electoral support and government participation

So far, we have seen that PRR parties are especially disliked. How is this moderated by electoral success and government experience? Does this increase perceived threat (H3) or rather legitimize the PRR (H4)? Figures 3 and 4 present the results of a regression (reported in Table 3 in Online Appendix A) in which sympathy is predicted by three-way interactions between both inparty and outparty, on the one hand, and electoral success (as a percentage of the electorate) and incumbency on the other. In the latter case, we included an additional interaction term for inparty incumbency, to distinguish the effect of government participation from that of being part of the same coalition. Both interactions were included simultaneously and visualized in turn in Figures 3 and 4. This analysis is vulnerable to confounding: it is plausible that moderate parties - which are relatively more likeable for political opponents - are generally more successful and more often asked to join coalitions. We therefore control for ideological distance on the left-right scale.

Starting with electoral support, Figure 3 provides support for the existence of legitimation effects. In the case of PRR parties (diamonds), larger PRR parties tend to receive more sympathy. This effect is significant among green, mainstream left, and mainstream right voters. All of this is in line with the expectation that PRR parties are legitimated by the support they receive from fellow citizens (H3), and 


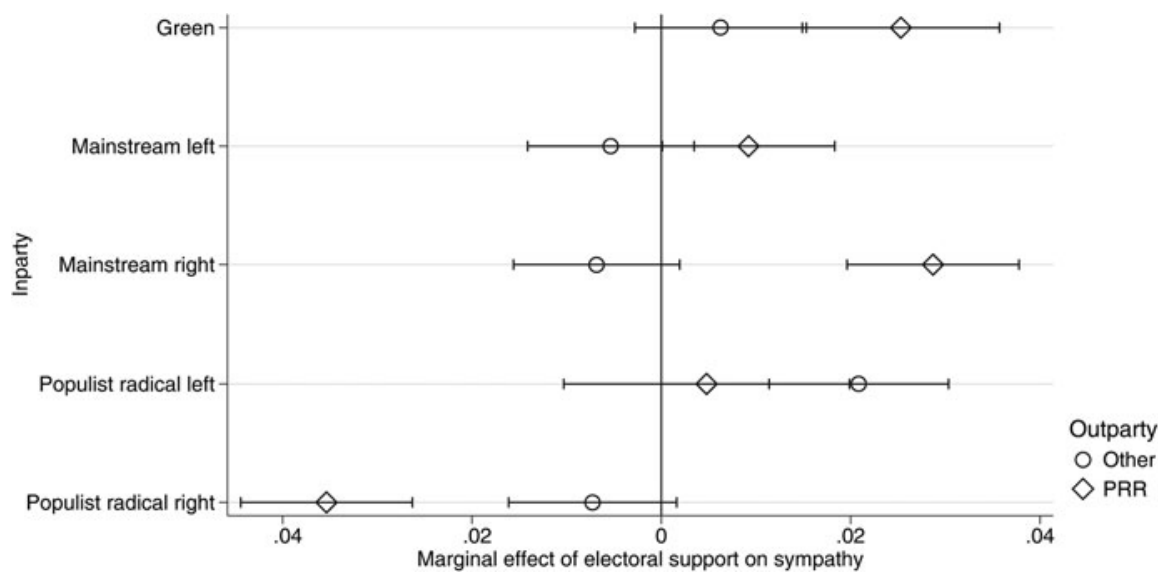

Figure 3. Marginal Effect of Electoral Support for a Party (in \%) on Sympathy for that Party, by PRR v. Other

especially on the mainstream right. Of course, other mechanisms might account for this correlation. In particular, more moderate parties might receive both more votes and sympathy from non-voters. However, it is notable that this pattern emerges even under control for ideological distance. Moreover, larger non-PRR parties are not liked systematically more than smaller ones. This suggests there is no general tendency for larger parties to appear more likeable to non-voters, controlling for ideological distance.

Figure 4 investigates the role of outparty government participation. Recall that any legitimation effect due to government inclusion should be visible beyond the PRR's coalition partners. Figure 4 therefore presents separate marginal effects of government inclusion for coalition partners and non-coalition partners. The left panel shows that coalition inclusion of non-PRR parties is associated with more sympathy among coalition partners (diamonds) but less sympathy among parties remaining outside the coalition (circles). This is clear evidence for coalition heuristics at work. In the case of PRR parties joining a government, by contrast, the pattern differs by party family. In the case of the mainstream right, a sympathy bonus is visible among coalition partners, but a sympathy penalty among non-coalition partners. For all other party families (for which incidences of co-governing with the PRR are more rare or absent), effects are uniformly negative (greens, mainstream left) or absent (populist radical left). In other words, government participation does not seem to legitimate PRR parties across the board; only their mainstream right coalition partners see the party in a more positive light. Among non-coalition partners, governing PRR parties appear less likeable.

\section{Study 2: Dutch panel data (LISS) \\ Data}

The second study relies on the Dutch Longitudinal Internet Studies for the Social Sciences (LISS) panel, which is recruited based on a population- 


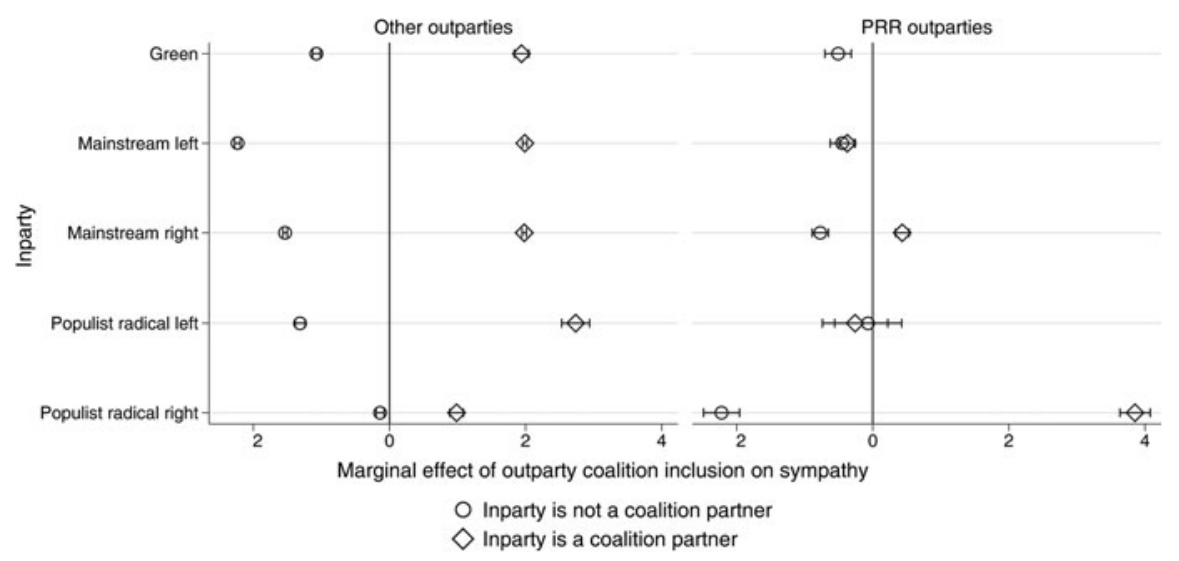

Figure 4. Marginal Effect of Incumbency of a Party on Sympathy for that Party, by PRR v. Other

representative sample and has run since 2007. Its respondents answer a yearly battery of questions on politics. In total, 8,205 unique individuals with non-missing observations took part during a part or the whole of the period 2008-18. Some $69 \%$ of the respondents had non-missing responses to the relevant questions for at least three waves; $59 \%$ for at least four waves; and $48 \%$ for five waves or more (on average they participated in 3.4 waves).

\section{Operationalization}

In the longitudinal analysis we again rely on a party sympathy measure on a scale from 0 (dislike) to 10 (like). This item was measured every year. We include sympathy towards six parties that were included throughout the period and which we classified into the same set of party families used in the CSES. The 'Greens' consists of the green party GroenLinks; the 'Mainstream left' of the Partij van de Arbeid (PvdA, Labour Party); the 'Mainstream right' of the Christen-Democratisch Appèl (CDA, Christian Democratic Appeal) and the Volkspartij voor Vrijheid en Democratie (VVD, People's Party for Freedom and Democracy); the 'Populist radical left' of the Socialistische Partij (SP, Socialist Party); and the 'Populist radical right' of the Partij voor de Vrijheid (PVV, Party for Freedom). The more recent PRR party, Forum voor Democratie (FvD, Forum of Democracy), is only included in the last wave and therefore not used in the longitudinal analysis.

We replicate the analysis with an alternative measure of an individual's outgroup bias towards partisans - that is, the supporters of various parties, rather than the parties themselves - that was included specifically for this purpose shortly after the 2019 wave. The concept of affective polarization was coined by Shanto Iyengar et al. (2012) to refer to increasing hostility between supporters of parties, and many of the normative concerns about the nefarious effects of affective polarization concern the way it sets citizens up against each other. James Druckman and Matthew Levendusky (2019) and Harteveld (2021) show that, indeed, citizens react differently to questions about fellow citizens from the way they react to 
questions about abstract elites. While the one-shot measurement included in LISS rules out any dynamic analysis, it does allow us to see whether the correlations at least replicate cross-sectionally with a more direct operationalization of antipathy between citizens. Respondents were asked to express their feelings towards the voters of the parties listed above on a continuous scale from 0 ('cold and negative'), through 50 ('neither warm nor cold'), to 100 ('positive and warm'). This 'feeling thermometer' is widely used in research in the US and has been shown to correlate to more elaborate measures of outgroup affect (see Iyengar et al. 2019).

Electoral support is measured by the share of LISS respondents who indicate they would vote for a particular party if elections were held today. ${ }^{12}$ Government inclusion in the case of the PVV took place during the data collection for the 2010 and 2011 waves, and hence we created a dummy for 'inclusion' with the value 1 for these two waves. ${ }^{13}$ From 2010 until the spring of 2012, the PVV provided informal support for a coalition of the Christian democrats (CDA) and conservative liberals (VVD). While the PVV did not supply ministers or provide support for all policy areas, the 'informality' of the inclusion episode was limited in practice. The party obtained several major policy concessions after lengthy negotiations and remained involved in the coalition throughout the period. It is therefore plausible that political opponents perceived the inclusion to involve real access to power, and hence potentially as either threatening or legitimated. In contrast to the election studies employed in Study 1, the yearly panel allows us to observe sympathy towards the PRR party during, rather than at the end of, a government inclusion episode.

\section{Models}

We start out by estimating models using dyadic data to map the entire 'affective' landscape. That means that, as in Study 1, there is a separate observation for each respondent's evaluation of each party. We model sympathy for the outparty as well as for outpartisans by the respondents' inparty family, the outparty family, and the interaction between the two. This model contains fixed effects for respondents, and so the explained variation is restricted to within-person variation, hence accounting for unobserved time-invariant confounders at the individual level. Because the single case provides only a limited number of inparty-outparty dyads, we do not estimate moderation by ideological distance formally, but rather evaluate $\mathrm{H} 2$ based on the descriptive data. In a second step, to estimate the effects of electoral success and government inclusion, we return to the non-dyadic data set, as our goal here is to model sympathy towards the PVV specifically. We predict sympathy towards the PVV by whether the PVV was included in government in that wave and by its level of support; we interacted both of these with the respondents' inparty family.

\section{Findings}

Dislike between PRR supporters and others

First, we look at patterns of sympathy expressed between parties. Figure 5 presents the scores handed out between each party family pair (averaged across all LISS 
waves), based on party sympathy. The patterns are highly comparable to those observed in the CSES. The PRR party (the PVV) is uniquely disliked by all other parties' supporters. This is especially true on the left (including the populist radical left SP), whose supporters hand out scores around or below 2. Dislike is somewhat weaker on the mainstream right, but still the PRR is the least-liked party among mainstream right supporters too. In return, PRR supporters dislike the mainstream in a very homogeneous way, handing out scores in the narrow (and rather cool) range of 3.0 to 4.5. In short, in the Netherlands as in the comparative data of Study 1, dislike between the PRR and non-PRR camps is strong. PRR supporters are most homogeneous in their dislike of mainstream parties, and the PRR systematically receives the lowest sympathy scores observed in the sample.

As mentioned above, the LISS data allow us to replicate these patterns in the last wave using items especially aimed to measure affective polarization towards supporters of the opposing political camps, rather than the abstract parties. Figure 6 shows that the patterns are very comparable: PRR supporters are disliked most, whereas PRR supporters dislike supporters of other parties relatively homogeneously. Dislike by PRR supporters towards green voters is of a similar magnitude to the dislike by mainstream voters towards the PRR, whereas their dislike of the mainstream left is somewhat lower than the dislike they receive in turn. In short, Figure 6 supports both $\mathrm{H} 1$ and $\mathrm{H} 2$, and encourages us to continue the analysis of the entire LISS panel using party sympathy measures.

\section{The role of success and government inclusion}

As mentioned above, informal coalition participation by the PVV occurred during the period covered by the LISS panel. This allows us to observe its effects in a within-respondents design. We start by visualizing the trends in sympathy scores handed out by various party family supporters towards the PVV in Figure 7. The government inclusion period is shaded. Clearly, most party supporters remained relatively unaffected by the inclusion. An important exception are the voters of the mainstream right, which consists of the two coalition partners (VVD and CDA). Their voters became much more sympathetic towards the PVV as the coalition participation started, and remained so during the second year of inclusion. For the supporters of coalition partners, this sympathy might be endogenous to the inclusion itself, and more importantly reflect a coalition heuristic (Fortunato and Stevenson 2013) rather than any deeper-rooted legitimation. After all, sympathy towards the PVV among this group disappeared immediately after government inclusion ended. The coalition collapsed in an antagonistic atmosphere as the PVV withdrew its support in April 2012. In short, the figure suggests no threat effect among any group of voters, and a hike in sympathy among coalition partners that likely reflects coalition heuristics rather than any deeper legitimation.

Still, these observations are based on an inspection of averages. We now turn to a formal within-respondent test of the effects of electoral success and government inclusion. Because we now use a single dependent variable (sympathy towards the PVV), we return to the original non-dyadic data. Figure 8 presents the marginal effects of both electoral success and government inclusion on PVV sympathy, derived from a model that includes both variables interacted with the inparty 


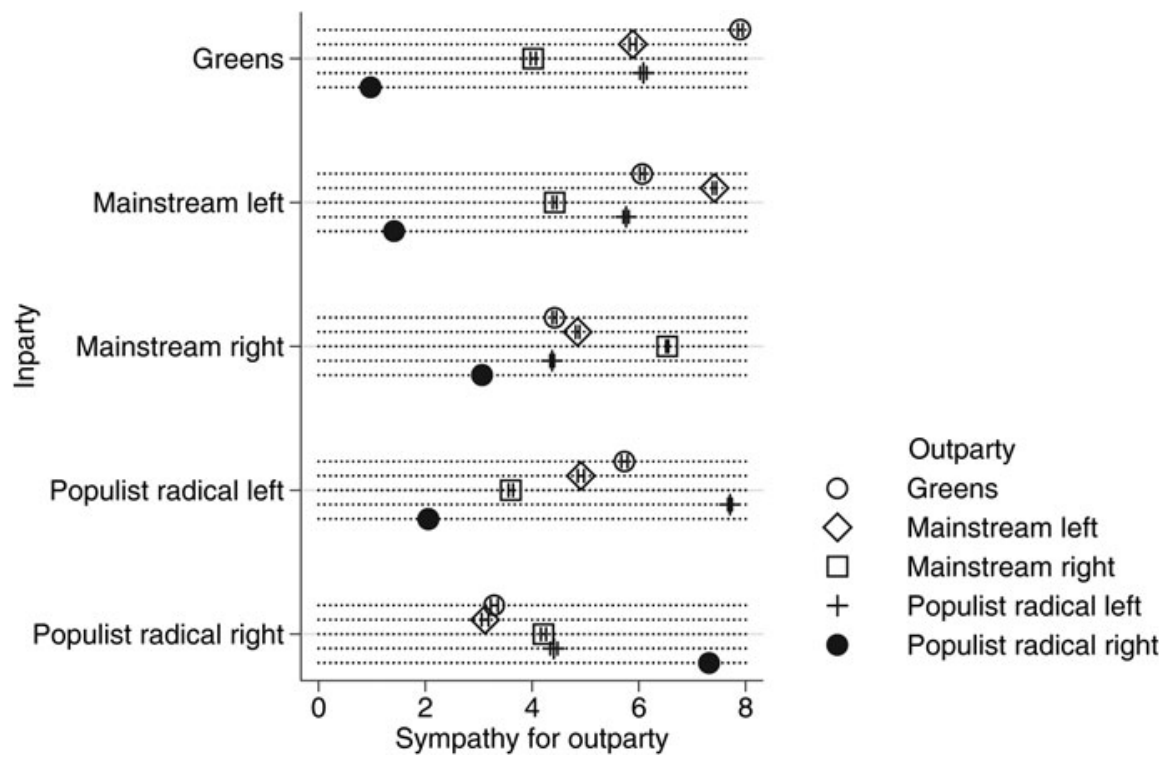

Figure 5. Predicted Sympathy towards Parties, by party family Note: Scores averaged over all LISS waves. Based on Online Appendix C, Table 1.

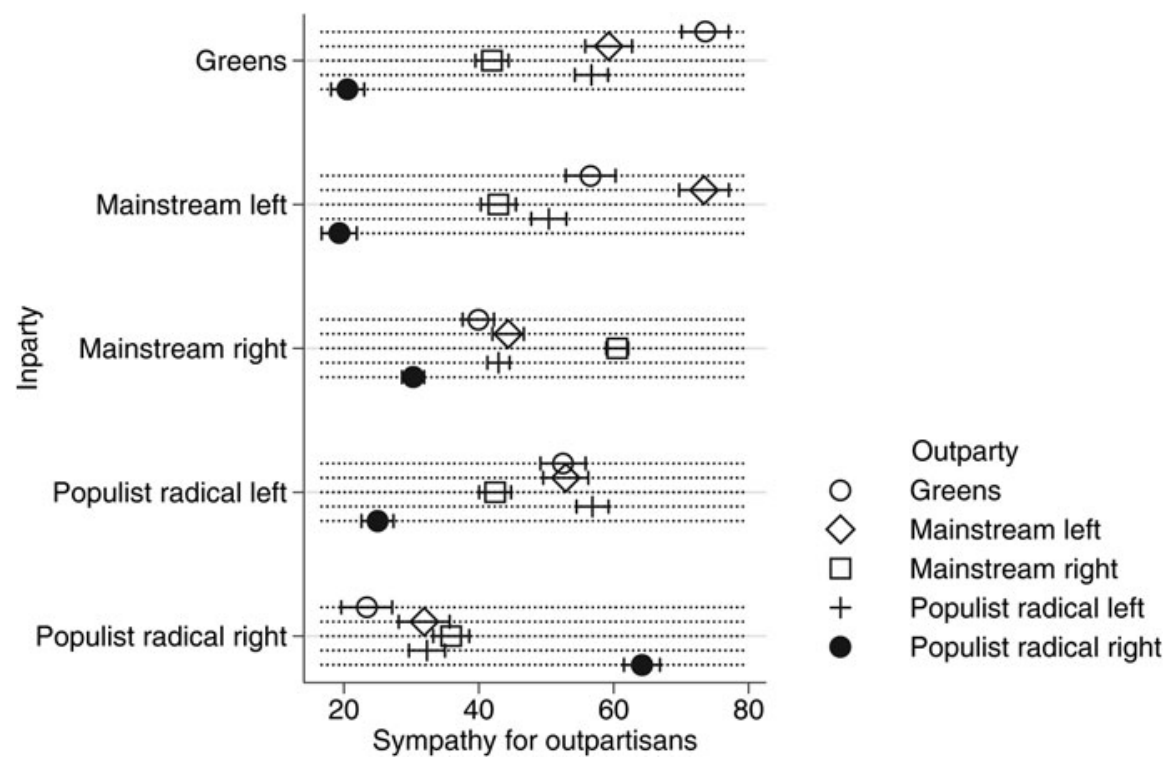

Figure 6. Predicted Sympathy towards Supporters, by party family Note: Based on Online Appendix C, Table 2. 


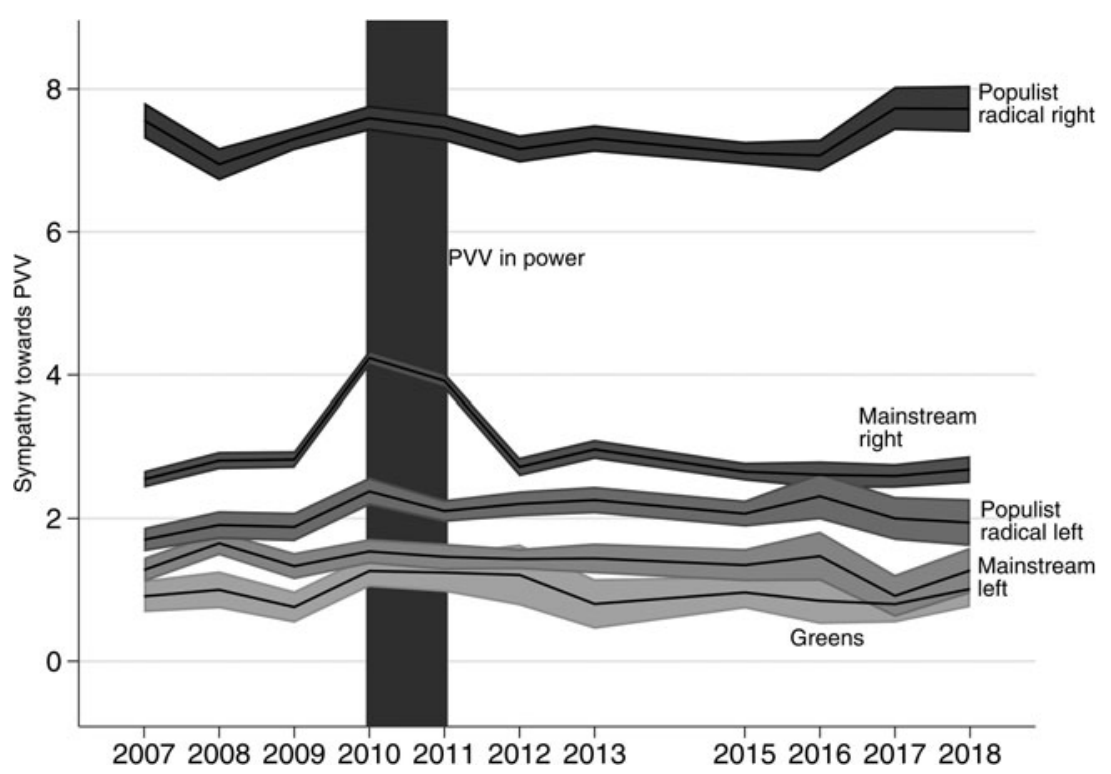

Figure 7. Trends in Sympathy towards the PVV, by inparty family Note: The PVV was informally included in government during data collection of the two waves in the shaded area.

families. By including fixed effects for respondents, the model predicts variation in PVV sympathy for a given respondent going through the inclusion episode.

Figure 8 shows that electoral success is not robustly associated with a change in PVV sympathy among any party family except the populist radical left SP, whose voters became more sympathetic to the PVV in periods when the party attracted more votes. At the time, SP voters were more likely to consider switching to the PVV than supporters of other left-wing parties (Van der Meer 2017), and electoral success by the PVV might indeed have legitimized this option for a part of this electorate. In line with the average trends in Figure 7, government inclusion is associated with a sympathy bonus among all voters, but only substantively so among the mainstream right (a bonus of a full point). As we have seen in Figure 7, this was likely a short-lived coalition heuristic, rather than any deeper re-evaluation of the PVV.

All in all, the LISS findings mirror the CSES findings to the extent that rising electoral fortunes for the PVV do not deter - and if anything positively encourage - other voters from developing sympathy for the PVV. Also in line with CSES, mainstream right coalition partners had higher levels of sympathy for the PRR during co-governing episodes. By contrast, the CSES did suggest a threat effect among other parties and non-coalition partners, but this does not play out in the Netherlands. Perhaps the PVV was generally less stigmatized and hence seen as less threatening - than some of its sister parties in Europe, suggesting that the extremity or stigma associated with a party further conditions the impact of electoral success. 

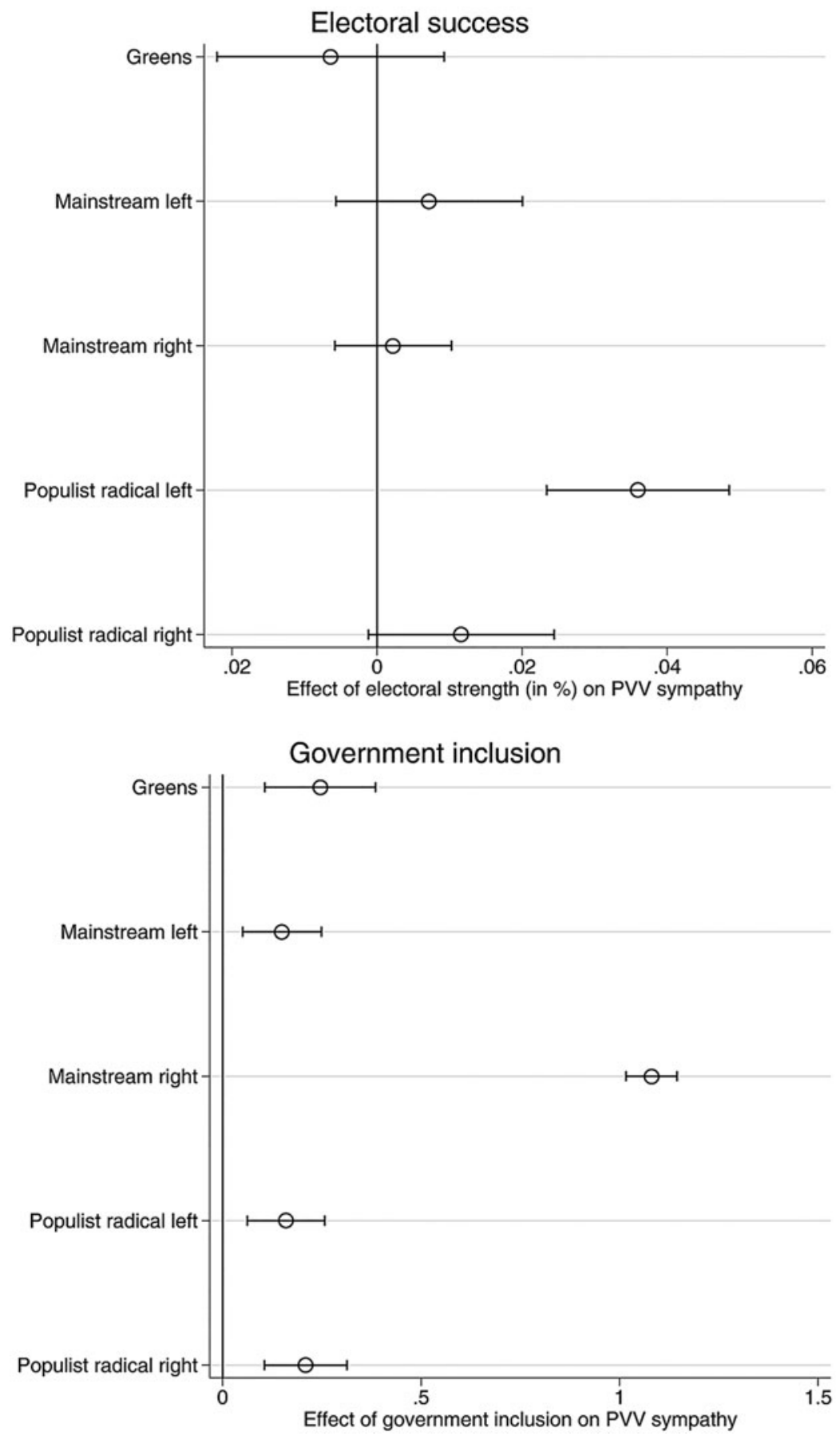

Figure 8. Marginal Effect of Electoral Success and Government Inclusion (FE model) Note: Based on Online Appendix C, Table 3. 


\section{Conclusions}

In this study we set out to investigate the impact of PRR parties on affective polarization, or dislike towards political outgroups. Due to PRR parties' emphasis on two moral divisions in society - a horizontal one between natives and non-natives, and a vertical one between the people and the elite - we expected their supporters to be highly disliking of (supporters of) mainstream parties, and to be highly disliked in turn. While previous studies have indeed reported on PRR 'exceptionalism' (Gidron et al. 2019b; also see Helbling and Jungkunz 2020) and on the stigma associated with PRR parties more generally (Harteveld et al. 2019), our study is the first to: (1) systematically differentiate dislike by and towards the populist radical right; (2) compare this with polarization surrounding the populist left; and (3) explore how such dislike is moderated by developments on the supply side (electoral success and government inclusion). We do so both by means of cross-country comparisons and through a longitudinal case study of the Netherlands.

We find that PRR parties indeed take a unique position in the 'affective landscape' by being at both the sending and receiving ends of uniquely strong dislike across all other party families (and their partisans). While the average outgroup sympathy scores between non-PRR parties lie between 4.5 and 5.5 on the 0 -to-10 sympathy scale, the coldest scale of the spectrum between 1.5 and 3 tends to be reserved for the PRR. PRR supporters return this strong dislike to a slightly lesser but equally homogeneous degree, making only minor distinctions between the mainstream left or right. Indeed, the affective distance between the PRR and other mainstream parties is less contingent on ideological differences (on the left-right spectrum or even nativism) than on the affective gaps between mainstream parties.

Our findings suggest that the dislike the PRR sends and receives is due to both their nativism and their populism. Ideological distance on nativism captures part of, but cannot fully account for, the dislike of PRR parties. In addition, populist radical left parties express and receive less dislike than supporters of PRR parties, but more than supporters of mainstream parties. This indicates that both the populist and the nativist messages trigger dislike and that, in particular, the combination of the two ingroup-outgroup messages can fuel affective polarization. 'PRR exceptionalism' seems to be informed by both the populist and the nativist component of these parties.

We expected that dislike towards the PRR could be either amplified or reduced by electoral success or government inclusion, as it might signal either acceptability or magnify the perceived threat. Here we find contrasting patterns. We find evidence in Study 1 that greater electoral success goes together with a sympathy bonus among supporters of mainstream parties (even under control for ideological distance). This could mean that greater success legitimates the PRR, but it is important to note that this effect did not replicate in the within-respondent analysis for the Netherlands in Study 2. Both studies suggest that government participation boosts sympathy among the mainstream right, but Study 1 shows this is restricted to coalition partners (and hence more properly thought of as a coalition heuristic). Among other parties, government participation has either a negative (Study 1) or very weakly positive (Study 2) effect. Hence, government participation by the PRR generally appears not to make these parties much more likeable, and in 
many cases even creates a backlash. That this backlash was not visible in the Netherlands (Study 2) could be due to a lower level of stigma associated with the PVV, or the fact that its inclusion was informal (albeit in a very influential way).

All in all, our findings suggest that increased electoral success (a cue from fellow citizens) might reduce affective polarization towards the PRR among a large swathe of voters, and hence pave the way for further growth, while inclusion in government (a cue from elites) does not do so, and might even create a backlash against the PRR. Still, dislike towards the PRR does not become watered down sufficiently to compensate the PRR affect penalty due to wider support for the PRR. In the aggregate, stronger PRR support still makes for an overall increase in affective polarization at the polity level. At the same time, the nature of the public reaction to growth and government inclusion likely depends on party characteristics (such as its extremity and stigma), which were beyond the scope of our study but deserve to be teased out in further research.

What does this tell us about affective polarization? First of all, it shows that understanding affective polarization is as much about the object of dislike as it is about the subject. The emergence, or a further increase in size, of the PRR party will impact affective polarization among mainstream party voters in a way that cannot be explained by any change on the part of these voters themselves. Especially in multiparty systems, the change in the offer is an important component of changes in affective polarization at large. Second, it suggests that perceived norm breaking has an important role in creating dislike between political camps. The PRR is disliked to an extent that goes beyond its mere ideological distance to many voters, and which overtakes the dislike towards populist radical left parties to a substantial degree. PRR parties' are seen by many to cross boundaries of the acceptable, creating high levels of affective distance, even among those closer in a conventional ideological sense (such as the mainstream right). Finally, it raises the question of how accurate the term 'polarization' - with its aggregate connotation - is to describe what is in fact a more specific phenomenon of unique dislike between those supporting the political mainstream (in most European countries more than $80 \%$ of the population) and a minority supporting the PRR. This strong antipathy can coexist with mild feelings between the vast majority of citizens. Hence, when studying the causes and consequences of affective polarization in societies at large, it would be fruitful to disentangle mutual evaluations within the political mainstream from those between mainstream and PRR.

Of course, our analysis leaves questions unanswered. Most importantly, our broad brush in CSES, combined with one case study, does not allow us to do justice to the great variety in PRR parties. They differ not only in size and incumbency status (as covered by this study), but also in ideological extremity, 'pariah status' and the relative weights of their populism and nativism. All of this will matter for the extent to which they attract or radiate dislike. This might explain why we only found moderate correlation between PRR party support and affective polarization at the macro level. Understanding which parties are most disliking, or disliked, would also shed a light on the mechanisms involved, and the way in which populism and nativism together create a unique moral dichotomy that divides the electorate in such a powerful way. 
Supplementary material. The supplementary material for this article can be found at https://doi.org/10. 1017/gov.2021.31.

Acknowledgements. We want to express our gratitude for the input we received from participants at the 2020 ECPR General Conference and the 2021 Comparative Politics Annual Conference (CPAC)'s 'Populism, Radicalism, and Democratic Backsliding' workshop. We also want to thank the reviewers and editors of Government and Opposition for their valuable feedback. This research was supported by the Dutch Research Council (016.Veni.195.159 and 016.Veni.175.203).

\section{Notes}

1 It is important to emphasize that according to most scholars authoritarianism forms a third core ideological feature of the PRR party family (see Mudde 2007; Rydgren 2007). Mudde (2007: 23) defines authoritarianism as 'the belief in a strictly ordered society, in which infringements of authority are to be punished severely'. In this article, however, we focus on nativism and populism rather than authoritarianism. First, the ingroup-outgroup distinctions emphasized by the PRR follow above all from their populism (vertically) and nativism (horizontally). Second, the stigma associated with the PRR is mostly due to their nativist stances, which are seen by large swathes of the population as crossing social norms (Blinder et al. 2013). 2 Note that although most studies of affective polarization examine polarization between partisans (e.g. the extent to which Democrats and Republicans in the US dislike each other (see Iyengar et al. 2019)), affective polarization could also concern opinion-based groups such as, for instance, Brexit-related identities (Hobolt et al. 2020). In this article we examine affective polarization along partisan lines but assume that in multiparty systems citizens differentiate in a more graduated way in their views of multiple outparties (Harteveld 2021; Wagner 2021).

3 Although in this article we will explore to what extent affective polarization is a consequence of populism, nativism, or a combination of the two (see below), our research design does not allow us to adjudicate empirically between the nativism and stigma mechanisms. Such an assessment would require information about the (degree of) 'pariah status' of PRR parties. See our concluding section.

4 Helbling and Jungkunz (2020) present an additional (structural) argument for dislike between PRR parties and the mainstream, taking these party identities as proxies for positions at the opposing end of the globalization cleavage. We cannot properly adjudicate the role of this mechanism in our data, but note that it is not incompatible with our understanding. Rather, it provides a potential explanation for why the PRR's focus on particular ingroups and outgroups resonates with many voters, and it is the prevalence of these Manichean messages that constitutes our theoretical starting point.

5 Populist radical left parties are parties that combine their populist message with a rejection of the skewed socioeconomic structure of capitalism. Such parties criticize neoliberalism and see economic inequality as one of the most important contemporary problems (March 2012). Hence, these parties strongly focus on welfare redistribution, and are therefore particularly attractive to economically vulnerable voters (Rooduijn et al. 2017). We focus on populist radical left parties because they form the second biggest type of populist parties, next to PRR parties (see Rooduijn et al. 2019).

6 Conversely, among PRR supporters, it is likely not perceived as particularly new, and hence threatening, if mainstream parties grow large or enter government.

7 By contrast, the reverse is again less likely: PRR supporters might arguably not be as impressed by high levels of support for, or government inclusion of, mainstream parties.

8 Replication material is available at https://doi.org/10.7910/DVN/RCRWTV.

9 Switzerland (1999, 2003, 2007, 2011), Denmark (2007), Norway (2017), Poland (2007), Romania (1996), Slovakia (2010) and Slovenia $(1996,2008)$. Several episodes of inclusion (including in Austria, the Netherlands and Hungary) are missing because CSES does not (yet) cover all elections in all participating countries.

10 See manifesto-project.wzb.eu. We first calculated the difference between the number of nativist instances on 'way of life' and 'multiculturalism' minus cosmopolitan stances on the same issues, and divided this by the total number of instances on both issues. This yields a variable that ranges between -1 (cosmopolitan) to 1 (nativist). For our dyad analysis, we calculated the absolute distance between two parties, which ranges from 0 to 2 .

11 We do not include demographic or attitudinal control variables because we are interested in the nominal 'dislike gap' between party families, not the conditional gap that remains after explaining sympathy by other variables. 
12 Online Appendix B compares trends in PVV support in LISS with election outcomes at national legislative and European elections that took place in the same year (albeit in different months). The trends show that support in LISS follows the same trends as the ballot box results.

13 By the time of data collection of the 2012 wave, the coalition had ended.

\section{References}

Adorno T, Frenkel-Brenswik E, Levinson DJ and Sanford RN (1950) The Authoritarian Personality. New York: Verso Books.

Anderson CJ and Tverdova YV (2001) Winners, Losers, and Attitudes about Government in Contemporary Democracies. International Political Science Review 22(4), 321-338. https://doi.org/10. 1177\%2F0192512101022004003.

Blais A and Gélineau F (2007) Winning, Losing and Satisfaction with Democracy. Political Studies 55(2), 425-441. https://doi.org/10.1111\%2Fj.1467-9248.2007.00659.x.

Blinder S, Ford R and Ivarsflaten E (2013) The Better Angels of Our Nature: How the Antiprejudice Norm Affects Policy and Party Preferences in Great Britain and Germany. American Journal of Political Science 57(4), 841-857. https://doi.org/10.1111/ajps.12030.

Bonikowski B (2017) Ethno-Nationalist Populism and the Mobilization of Collective Resentment. British Journal of Sociology 68, S181-S213. https://doi.org/10.1111/1468-4446.12325.

Boxell L, Gentzkow M and Shapiro JM (2020) Cross-Country Trends in Affective Polarization. National Bureau of Economic Research Paper 26669. www.nber.org/papers/w26669.

Brewer MB (1999) The Psychology of Prejudice: Ingroup Love and Outgroup Hate? Journal of Social Issues 55(3), 429-444.

Carter E (2018) Right-Wing Extremism/Radicalism: Reconstructing the Concept. Journal of Political Ideologies 23(2), 157-182. https://doi.org/10.1080/13569317.2018.1451227.

Cohen GL (2003) Party Over Policy: The Dominating Impact of Group Influence on Political Beliefs. Journal of Personality and Social Psychology 85(5), 808. https://psycnet.apa.org/doi/10.1037/0022-3514.85.5.808.

CSES (2019) CSES Integrated Module Dataset Phase 2 Release (Dataset and Documentation), 17 October 2019 Version. Comparative Study of Electoral Systems (www.cses.org). https://doi.org/10.7804/cses.imd.2019-10-17.

Dahlberg S (2013) Does Context Matter: The Impact of Electoral Systems, Political Parties and Individual Characteristics on Voters' Perceptions of Party Positions. Electoral Studies 32(4), 670-683. https://doi. org/10.1016/j.electstud.2013.02.003.

De Cleen B, Glynos J and Mondon A (2018) Critical Research on Populism: Nine Rules of Engagement. Organization 25(5), 649-661. https://doi.org/10.1177\%2F1350508418768053.

Döring H and Regel S (2019) Party Facts: A Database of Political Parties Worldwide. Party Politics 25(2): 97-109. https://doi.org/10.1177\%2F1354068818820671.

Druckman JN and Levendusky MS (2019) What Do We Measure When We Measure Affective Polarization? Public Opinion Quarterly 83(1), 114-122. https://doi.org/10.1093/poq/nfz003.

Feldman S and Stenner K (1997) Perceived Threat and Authoritarianism. Political Psychology 18(4), 741770. https://doi.org/10.1111/0162-895X.00077.

Finkel EJ et al. (2020) Political Sectarianism in America. Science 370(6516), 533-536. https://oi.org/10. $1126 /$ science.abe1715.

Fortunato D and Stevenson RT (2013) Perceptions of Partisan Ideologies: The Effect of Coalition Participation. American Journal of Political Science 57(2), 459-477. https://doi.org/10.1111/j.1540-5907. 2012.00623.x.

Gidron N, Adams J and Horne W (2019a) Toward a Comparative Research Agenda on Affective Polarization in Mass Publics. APSA-CP Newsletter 29(1), 30-36. https://papers.ssrn.com/sol3/papers. cfm?abstract_id $=3391062$.

Gidron N, Adams J and Horne W (2019b) Who Dislikes Whom? The Drivers of Affective Polarization in Multi-Party Systems. Annual Conference of the American Political Science Association.

Harteveld E (2021) Fragmented Foes: Affective Polarization in the Multiparty Context of the Netherlands. Electoral Studies 71, 102332. https://doi.org/10.1016/j.electstud.2021.102332.

Harteveld E, Kokkonen A and Dahlberg S (2017) Adapting to Party Lines: The Effect of Party Affiliation on Attitudes to Immigration. West European Politics 40(6), 1177-1197. https://doi.org/10.1080/ 01402382.2017.1328889. 
Harteveld E, Dahlberg S, Kokkonen A and van der Brug W (2019) Social Stigma and Support for the Populist Radical Right: An Experimental Study. Scandinavian Political Studies 42(3-4), $296-307$. https://doi.org/10.1111/1467-9477.12153.

Hawkins KA (2010) Venezuela's Chavismo and Populism in Comparative Perspective. Cambridge: Cambridge University Press.

Hawkins KA and Kaltwasser CR (2019) Introduction: The Ideational Approach. In Hawkins KA, Carlin RE, Liitvay L and Rovira Kaltwasser C (eds), The Ideational Approach to Populism: Concept, Theory and Analysis. London: Routledge, pp. 1-24.

Helbling M and Jungkunz S (2020) Social Divides in the Age of Globalization. West European Politics 43 (6), 1187-1210. https://doi.org/10.1080/01402382.2019.1674578.

Hetherington MJ and Rudolph TJ (2015) Why Washington Won't Work: Polarization, Political Trust, and the Governing Crisis. Chicago: University of Chicago Press.

Hobolt SB, Leeper TJ and Tilley J (2020) Divided by the Vote: Affective Polarization in the Wake of the Brexit Referendum. British Journal of Political Science, published early online, July. https://doi.org/10. $1017 /$ S0007123420000125.

Ionescu G and Gellner E (1969) Introduction. In Ionescu G and Gellner E (eds), Populism: Its Meaning and National Characteristics. London: Weidenfeld and Nicolson, pp. 1-5.

Iyengar S, Sood G and Lelkes Y (2012) Affect, Not Ideology: A Social Identity Perspective on Polarization. Public Opinion Quarterly 76(3), 405-431. https://doi.org/10.1093/poq/nfs038.

Iyengar S, Lelkes Y, Levendusky M, Malhotra N and Westwood SJ (2019) The Origins and Consequences of Affective Polarization in the United States. Annual Review of Political Science 22, 129-146. https://doi. org/10.1146/annurev-polisci-051117-073034.

Kalmoe NP and Mason L (2018) Lethal Mass Partisanship: Prevalence, Correlates, and Electoral Contingencies. Annual Conference of the American Political Science Association. www.dannyhayes.org/ uploads/6/9/8/5/69858539/kalmoe__mason_ncapsa_2019_-_lethal_partisanship_-_final_lmedit.pdf.

Lelkes Y (2018) Affective Polarization and Ideological Sorting: A Reciprocal, Albeit Weak, Relationship. Forum 16(1), 67-79. http://dx.doi.org/10.1515/for-2018-0005.

Lewis P, Clarke S, Barr C, Holder J and Kommenda N (2018) Revealed: One in Four Europeans Vote Populist. Guardian, 20 November. www.theguardian.com/world/ng-interactive/2018/nov/20/revealedone-in-four-europeans-vote-populist.

March L (2012) Problems and Perspectives of Contemporary European Radical Left Parties: Chasing a Lost World or Still a World to Win?. International Critical Thought 2(3), 314-339. http://dx.doi.org/10.1080/ 21598282.2012.706777.

Martherus JL, Martinez AG, Piff PK and Theodoridis AG (2021) Party Animals? Extreme Partisan Polarization and Dehumanization. Political Behavior 2021(2), 517-540. https://doi.org/10.1007/ s11109-019-09559-4.

Meguid BM (2005) Competition between Unequals: The Role of Mainstream Party Strategy in Niche Party Success. American Political Science Review 99(3), 347-359. https://doi.org/10.1017/S0003055405051701.

Meléndez C and Kaltwasser CR (2021) Negative Partisanship towards the Populist Radical Right and Democratic Resilience in Western Europe. Democratization 28(5), 949-969. https://doi.org/10.1080/ 13510347.2021.1883002.

Mény Y and Surel Y (2002) Democracies and the Populist Challenge. New York: Palgrave.

Moffitt B (2018) The Populism/Anti-Populism Divide in Western Europe. Democratic Theory 5(2), 1-16. https://doi.org/10.3167/dt.2018.050202.

Mudde C (2004) The Populist Zeitgeist. Government and Opposition: An International Journal of Comparative Politics 39(4), 541-563. http://dx.doi.org/10.1111/j.1477-7053.2004.00135.x.

Mudde C (2007) Populist Radical Right Parties in Europe. Cambridge: Cambridge University Press.

Panizza F (2005) Introduction: Populism and the Mirror of Democracy. In Panizza F (ed.), Populism and the Mirror of Democracy. London: Verso, pp. 1-31.

Reiljan A (2020) 'Fear and Loathing across Party Lines' (Also) in Europe: Affective Polarisation in European Party Systems. European Journal of Political Research 59(2), 376-396. https://doi.org/10. 1111/1475-6765.12351.

Rooduijn M (2019). State of the Field: How to Study Populism and Adjacent Topics? A Plea for Both More and Less Focus. European Journal of Political Research 58(1), 362-372. https:/doi.org/10.1111/1475-6765.12314. 
Rooduijn M, Van der Brug W and De Lange SL (2016) Expressing or Fuelling Discontent? The Relationship between Populist Voting and Political Discontent. Electoral Studies 43, 32-40. https://doi. org/10.1016/j.electstud.2016.04.006.

Rooduijn M, Burgoon B, Van Elsas EJ and Van de Werfhorst HG (2017) Radical Distinction: Support for Radical Left and Radical Right Parties in Europe. European Union Politics 18(4), 536-559. https://doi. org/10.1177\%2F1465116517718091.

Rooduijn M, Van Kessel S, Froio C, Pirro A, De Lange S, Halikiopoulou D, Lewis P, Mudde C and Taggart P (2019) The PopuList: An Overview of Populist, Far Right, Far Left and Eurosceptic Parties in Europe. www.popu-list.org.

Rydgren J (2007) The Sociology of the Radical Right. Annual Review Sociology 33, 241-262. https://oi.org/ 10.1146/annurev.soc.33.040406.131752.

Stavrakakis Y (2014) The Return of 'the People': Populism and Anti-Populism in the Shadow of the European Crisis. Constellations 21(4), 505-517. http://dx.doi.org/10.1111/cons.2014.21.issue-4.

Stavrakakis Y and Katsambekis G (2019) The Populism/Anti-Populism Frontier and its Mediation in Crisis-Ridden Greece: From Discursive Divide to Emerging Cleavage?. European Political Science 18 (1), 37-52. http://dx.doi.org/10.1057/s41304-017-0138-3.

Strickler R (2018) Deliberate with the Enemy? Polarization, Social Identity, and Attitudes toward Disagreement. Political Research Quarterly 71(1), 3-18. https://doi.org/10.1177\%2F1065912917721371.

Tajfel H and Turner JC (1979) An Integrative Theory of Intergroup Conflict. In Austin WG and Worchel S (eds), The Social Psychology of Intergroup Relations. Monterey, CA: Brooks/Cole, pp. 33-47.

Tappin BM and McKay RT (2019) Moral Polarization and Out-Party Hostility in the US Political Context. Journal of Social and Political Psychology 7(1), 213-245. https://doi.org/10.5964/jspp.v7i1.1090.

Van der Meer T (2017) Niet de Kiezer is gek. Houten: Spectrum.

Volkens A, Krause W, Lehmann P, Theres M, Merz N, Regel S and Weßels B (2019) The Manifesto Data Collection. Manifesto Project (MRG/CMP/MARPOR). Version 2019b. Wissenschaftszentrum Berlin für Sozialforschung (WZB).

Wagner M (2021) Affective Polarization in Multiparty Systems. Electoral Studies 69, 102199. https://doi. org/10.1016/j.electstud.2020.102199.

Westwood SJ, Iyengar S, Walgrave S, Leonisio R, Miller L and Strijbis O (2018) The Tie that Divides: Cross-National Evidence of the Primacy of Partyism. European Journal of Political Research 57(2), 333354. https://doi.org/10.1111/1475-6765.12228.

Zaller JR (1992) The Nature and Origins of Mass Opinion. Cambridge: Cambridge University Press.

Cite this article: Harteveld E, Mendoza P, Rooduijn M (2022). Affective Polarization and the Populist Radical Right: Creating the Hating? Government and Opposition: An International Journal of Comparative Politics 57, 703-727. https://doi.org/10.1017/gov.2021.31 